\title{
Morphology and size of the particles emitted from a gasoline-direct-injection-engine vehicle and their ageing in an environmental chamber
}

\author{
Jiaoping Xing ${ }^{1,2}$, Longyi Shao ${ }^{1}$, Wenbin Zhang ${ }^{3}$, Jianfei Peng ${ }^{4}$, Wenhua Wang ${ }^{1}$, Shijin Shuai ${ }^{3}$, Min $\mathrm{Hu}^{4}$, and \\ Daizhou Zhang ${ }^{5}$ \\ ${ }^{1}$ State Key Laboratory of Coal Resources and Safe Mining, School of Geoscience and Surveying Engineering, \\ China University of Mining and Technology, Beijing 100083, China \\ ${ }^{2} 2011$ Collaborative Innovation Center of Jiangxi Typical Trees Cultivation and Utilization, \\ School of Forestry, Jiangxi Agricultural University, Nanchang 330045, China \\ ${ }^{3}$ State Key Laboratory of Automotive Safety and Energy, Department of Automotive Engineering, \\ Tsinghua University, Beijing 100084, China \\ ${ }^{4}$ State Key Joint Laboratory of Environmental Simulation and Pollution Control, College of Environmental Sciences and \\ Engineering, Peking University, Beijing 100871, China \\ ${ }^{5}$ Faculty of Environmental and Symbiotic Sciences, Prefectural University of Kumamoto, \\ Kumamoto 862-8502, Japan
}

Correspondence: Longyi Shao (shaol@ cumtb.edu.cn) and Daizhou Zhang (dzzhang@pu-kumamoto.ac.jp)

Received: 15 July 2019 - Discussion started: 2 September 2019

Revised: 30 January 2020 - Accepted: 31 January 2020 - Published: 6 March 2020

\begin{abstract}
Air pollution is particularly severe in developing megacities, such as Beijing, where vehicles equipped with modern gasoline-direct-injection (GDI) engines are becoming one of major sources of the pollution. This study presents the characteristics of individual particles emitted by a GDI vehicle and their ageing in a smog chamber under the Beijing urban environment, as part of the Atmospheric Pollution \& Human Health (APHH) research programme. Using transmission electron microscopy, we identified the particles emitted from a commercial GDI-engine vehicle running under various conditions, namely cold-start, hotstart, hot stabilized running, idle, and acceleration states. Our results showed that most of the particles were organic, soot, and Ca-rich ones, with small quantities of S-rich and metal-containing particles. In terms of particle size, the particles exhibited a bimodal distribution in number vs size, with one mode at $800-900 \mathrm{~nm}$ and the other at $140-240 \mathrm{~nm}$. The numbers of organic particles emitted under hot-start and hot stabilized states were higher than those emitted under other conditions. The number of soot particles was higher under cold-start and acceleration states. Under the idle state, the proportion of Ca-rich particles
\end{abstract}

was highest, although their absolute number was low. In addition to quantifying the types of particles emitted by the engine, we studied the ageing of the particles during $3.5 \mathrm{~h}$ of photochemical oxidation in an environmental chamber under the Beijing urban environment. Ageing transformed soot particles into core-shell structures, coated by secondary organic species, while the content of sulfur in Ca-rich and organic particles increased. Overall, the majority of particles from GDI-engine vehicles were organic and soot particles with submicron or nanometric size. The particles were highly reactive; they reacted in the atmosphere and changed their morphology and composition within hours via catalysed acidification that involved gaseous pollutants at high pollution levels in Beijing.

\section{Highlights.}

- GDI-engine vehicles emitted a large amount of both primary and secondary organic aerosol (SOA).

- Higher numbers of organic particles were emitted under hot stabilized running and hot-start states. 
- Sulfate and secondary organic aerosol formed on the surface of primary particles after ageing.

- Particles aged rapidly by catalysed acidification under high pollution levels in Beijing.

\section{Introduction}

Air pollution caused by $\mathrm{PM}_{2.5}$ in megacities such as Beijing, the capital city of China, is of public and academic concern due to its environmental impacts (Bond et al., 2013; Huang et al., 2014; Liu et al., 2017) and adverse health effects (Chart-asa and Gibson, 2015; Shao et al., 2017b). Motor vehicle emissions are one of the most significant sources of airborne particles in the urban atmosphere (Hwa and Yu, 2014) and contribute up to $31 \%$ of primary particulate emissions of $\mathrm{PM}_{2.5}$ in Beijing (Yu et al., 2013). Moreover, secondary aerosol formation associated with traffic emissions is a major process leading to the rapid increase in $\mathrm{PM}_{2.5}$, which results in severe haze episodes (Huang et al., 2014). Although emissions from gasoline engines are lower than those from diesel engines (Alves et al., 2015), the number of gasoline-powered vehicles in urban areas greatly exceeds that of diesel-powered vehicles. The total number of vehicles in China reached 310 million in 2017, and about $70 \%$ of these were powered by gasoline engines (National Bureau of Statistics of China, 2018). There are two main types of gasoline engines, namely conventional multipoint port-fuelinjection (PFI) engines and gasoline-direct-injection (GDI) engines. In recent years, the demand for engines with high efficiency and low fuel consumption has led to an increasing use of GDI engines in light-duty passenger cars. The market share of GDI-engine vehicles has increased dramatically over the past decade and was estimated to reach $50 \%$ of new gasoline vehicles sold in 2016 (Zimmerman et al., 2016). In Beijing and northern China, the vehicle emissions have become a more concerning issue in terms of air pollution when the emissions from coal combustion were seriously reduced after the Clean Air Action Plan in Beijing since 2017 (Chang et al., 2019; Chen et al., 2019; Zhang et al., 2019a). In spite of this, regional transport of coal-burning emissions from the surrounding areas can still influence the urban air sometimes severely in winter (Ma et al., 2017; Zhang et al., 2019b).

The number, mass, and size distribution of particles emitted from GDI-engine vehicles have been studied (Khalek et al., 2010; Maricq et al., 2011; Baral et al., 2011). The size distribution usually has an accumulation mode with the maxima in the diameter range of 100-300 nm. Major components of the particles include elemental carbon (EC), organic carbon, and ash (Giechaskiel et al., 2014). Besides particulate matter, the engines emit gaseous hydrocarbon compounds. These compounds might form particles, or be adsorbed on the surface of particle aggregates, leading to the growth of the particles in the engine emission (Luo et al., 2015). Relatively high particle emissions by GDI-engine vehicles have prompted studies on the effects of engine operating parameters and fuel composition on the characteristics of the particles (Hedge et al., 2011; Szybist et al., 2011). It has been found that, in general, emissions under the cold-start condition make up the major contribution to the total amount of PM emissions from GDI engines (Chen and Stone, 2011). Studies have also demonstrated that the highest particle emissions from GDI engines in number concentration occur under the acceleration state during transient vehicle operations (Chen et al., 2017).

Studies have also shown that gasoline vehicles are an important source of secondary aerosol precursors in urban areas (Suarez-Bertoa et al., 2015). Secondary aerosols can be formed via gas-phase reactions of volatile organic compounds and multiphase and heterogeneous processes of primary particles (Zhu et al., 2017). Experiments performed in environmental chambers demonstrated that the mass of secondary aerosols derived from precursors could exceed that of directly emitted aerosols (Jathar et al., 2014). The occurrence of secondary aerosols on particles could change the properties of particles in terms of size, mass, chemical composition, morphology, and optical and hygroscopic parameters. These changes, in turn, might affect the environmental impact of the particles significantly, for instance in terms of visibility, human health, weather, and energy budgets (Laskin et al., 2015; Peng et al., 2017). In general, the ageing processes of primary particles in the atmosphere are studied to understand their climate effects (Niu et al., 2011). However, the lack of data on primary particles emitted by gasoline engines hinders a deep understanding of the roles and activities of the particles in ambient air pollution and relevant environmental effects.

The Atmospheric Pollution \& Human Health (APHH) research programme aimed to explore the sources and processes affecting urban atmospheric pollution in Beijing. Details regarding this project are given in Shi et al. (2019). To address one of the aims of the AIRPOLL-Beijing (Sources and Emissions of Air Pollutants in Beijing) and AIRPROBeijing (the integrated study of Air Pollution Processes in Beijing), we employed a dedicated experiment to investigate the characteristics of the individual particles, in terms of the number concentration and size distribution, emitted from a GDI-engine vehicle during a real-world driving cycle for a chassis dynamometer test, i.e. the Beijing driving cycle (BDC). Various test modes were introduced to accurately evaluate the emissions from light- or medium-duty vehicles. Furthermore, experiments were conducted in an environmental chamber to investigate the ageing processes of particles emitted by GDI-engine vehicles in ambient air in Beijing. We utilized a transmission electron microscope equipped with an Oxford energy-dispersive X-ray spectrometer (TEM-EDX) to identify the morphology, size, and elemental composition of particles emitted by the GDI-engine vehicle when it was 
running under different states. Particles before and after $3.5 \mathrm{~h}$ of ageing in the chamber were compared on the basis of the TEM-EDX analysis. The TEM-EDX analysis provides the information on the internal inhomogeneity, mixing state, and surface characteristics of individual particles and has been used to analyse the aerosol particles (Li and Shao, 2009; Loh et al., 2012; Adachi and Buseck, 2015; Shao et al., 2017a). The experimental design allows for the study of the physical and chemical characteristics of the particles emitted from the GDI-engine vehicles as well as their ageing in a simulated urban atmosphere. The purpose of this study is to evaluate the individual characteristics and the ageing process of primary particles emitted by a GDI-engine vehicle, to investigate the ageing processes of such particles in the atmosphere, and to deepen the understanding of the environmental impact of gasoline-powered vehicle emissions.

\section{Material and methods}

\subsection{Test vehicle, fuels, and test procedure}

The GDI-engine vehicle utilized in the experiment complies with the China Phase 4 (equivalent to Euro 4) standard. It uses a three-way catalyst to reduce gaseous emissions. The GDI (model GDI-1.4-T) in the test vehicle is recognized as a representative of leading-edge designs of gasoline engines because of its advanced engine technology such as its better fuel-burning efficiency and lower greenhouse gas emissions than other types of engine. Vehicles equipped with such GDI engines constitute the majority of light-duty vehicles in China, especially in large cities like Beijing. Details of the engine used in this study are listed in Table S1 in the Supplement. The fuel used in the experiment is a commercial gasoline blend of common quality in China. The properties of the fuel were measured by SGS-CSTC Standards Technical Services Co., Ltd., China, and are listed in Table S2. The fuel has a research octane number (RON) of 93 and is a fifth-stage gasoline. It contains $36.7 \%$ aromatics and $15.4 \%$ olefins in volume and $6 \%$ sulfur in mass, representing a typical fifth-stage gasoline in China (with high aromatics), and is now widely used in Beijing. The experiments were conducted within repeated BDCs, and one BCD included a $200 \mathrm{~s}$ cold-start phase followed by an 867 s hot stabilized running phase. The conditions during a BDC in the experiments are illustrated in Fig. S1a in the Supplement. The cold-start state was achieved by starting the vehicle with a period of small accelerations, while the hot stabilized running state had multiple periods of large acceleration and a maximum velocity of $50 \mathrm{~km} \mathrm{~h}^{-1}$. The BDC, characterized by a higher proportion of idling periods and a lower acceleration speed than the New European Driving Cycle (NEDC), was performed to simulate the repeated braking and acceleration on road in megacities such as Beijing.
All tests were performed on a Euro 5/LEV2/Tier 2-capable test cell on a 48 in. single-roll chassis dynamometer at the State Key Laboratory of Automobile Safety and Energy Conservation at Tsinghua University. The test procedure for each run was as follows: fuel change, BDC preparation, soak, cold-start BDC test, and hot-start BDC test. After fuel change and BDC preparation, the test vehicle was then conditioned with an overnight soak for more than $10 \mathrm{~h}$. The soak room temperature was maintained between 20 and $30^{\circ} \mathrm{C}$. Due to the limitation of the facilities and available running time, a hot-start test was conducted within $5 \mathrm{~min}$ of the cold-start test. A dilution unit was applied to dilute the exhaust from the tailpipe to $1 / 10$ in volume using synthetic air composed of $79 \% \mathrm{~N}_{2}$ and $20 \% \mathrm{O}_{2}$ in order to obtain the concentrations suitable for subsequent measurements and suppress possible coagulation. The number concentration of the emitted particles was monitored by a Cambustion Fast Particle Analyzer Differential Mobility Spectrometer 500 (DMS 500). The maximum measurable number concentration of DMS 500 was $10^{11}(\mathrm{~d} N / \mathrm{d} \log \mathrm{Dp} / \mathrm{cc})$ after the dilution (Petzold et al., 2011). For the analyses of individual particles, six to eight samples were collected during one BDC test. At least one sample was collected under each running state (i.e. coldstart, hot-start, idle state, acceleration state, or hot stabilized running state). The driving-cycle test was repeated at least twice. Two or more samples were obtained for each running state. A single-stage cascade impactor (KB-2, Qingdao Jinshida Company) was mounted to the exit of the tailpipe after the dilution unit. The emitted particles were collected onto 300-mesh copper TEM grids, which were covered with a carbon-coated formvar film. The flow rate was $1.0 \mathrm{~L} \mathrm{~min}^{-1}$, and the cut-off diameter of the impactor for $50 \%$ collection efficiency was $0.25 \mu \mathrm{m}$ if the density of the particles was $2 \mathrm{~g} \mathrm{~cm}^{-3}$. For each sample, the collection time was $60 \mathrm{~s}$.

\subsection{Environmental-chamber experiments}

Particles from the GDI-engine vehicle were introduced into an environmental chamber and exposed to sunlight. The chamber, made of Teflon ${ }^{\mathrm{TM}}$ perfluoroalkoxy (PFA) polymer in order to achieve a high transmission of ultraviolet light, has an internal volume of $1.2 \mathrm{~m}^{3}$. Ambient sunlight was used as the driving force for photochemical reactions in the chamber, in an environment close to actual open air. Before the experiments, the chamber was cleaned by flushing with zero air for approximately $12 \mathrm{~h}$ and illuminated with sunlight to remove residues that could influence the experiments. $\mathrm{H}_{2} \mathrm{O}_{2}$ $(1 \mathrm{~mL}, 30 \%)$, together with the vehicle emission, was injected into the chamber to generate $\mathrm{OH}$ exposure. The $\mathrm{OH}$ exposure at the end of the experiments reproduced extreme oxidation processes, which were equivalent to cases of an oxidation process lasting more than $10 \mathrm{~d}$ in Beijing ambient air if the $24 \mathrm{~h}$ mean concentration of $\mathrm{OH}$ is $10^{6}$ molecules $\mathrm{cm}^{-3}$ (Lu et al., 2013). The ageing experiments for the gasoline exhausts were carried out with a relatively high $\mathrm{OH}$ expo- 
sure compared to ambient conditions in order to obtain the ageing process. This method and the amount of $\mathrm{H}_{2} \mathrm{O}_{2}$ have been frequently used in smog chamber experiments (Song et al., 2007, 2019). After the injection, the experiments were conducted from approximately 13:00 to 17:00 local time under the sun, with the relative humidity being kept at around $50 \%$. The global solar radiation when the tests were carried out was approximately $318 \mathrm{~W} \mathrm{~m}^{-2}$. After $3.5 \mathrm{~h}$ of ageing, the particles in the chamber were collected onto mesh TEM grids using the impactor. The collection time for each sample was $120 \mathrm{~s}$. The schematic diagram of the experimental system is presented in Fig. S1b.

\subsection{TEM-EDX and scanning transmission electron microscopy (STEM) analyses}

The particles in the samples were examined using a Tecnai G2 F30 field emission high-resolution transmission electron microscope (FE-HRTEM). This microscope is also equipped with an Oxford EDX and a STEM (scanning transmission electron microscopy) unit with a high-angle annular darkfield detector (HAADF). The EDX can detect elements with the atom number larger than 5 (B) in a single particle. The HAADF can detect the distribution of a certain element by mapping the distribution of the element in a particle. The TEM was operated with the acceleration voltage of $300 \mathrm{kV}$. EDX spectra were firstly collected for 20 live seconds to minimize the influence of radiation exposure and potential beam damage and then for 90 live seconds for a range of possible elements. Copper was excluded from the analysis because of interference from the TEM grids, which were made of copper.

To ensure the representativeness of the analysed particles, more than 150 particles from at least three random areas were analysed from the centre and periphery of the sampling spot on each grid. All individual particles larger than $50 \mathrm{~nm}$ in the selected areas were analysed. The TEM images were digitized using an automated fringe image processing system called the Microscopic Particle Size of Digital Image Analysis System (UK) to project the surface areas of the particles. The equivalent spherical diameter of a particle was calculated from its projected area, expressed as $\sqrt{4 A / \pi}$, where $A$ was the projected area. The electron microscope analysis of individual particles was very time-consuming, which hindered us from analysing more particles from multiple-engine emissions. There are differences in emissions from vehicle to vehicle even for vehicles with same model engines. Only one GDI vehicle, the type of which constitutes the majority of light-duty vehicles in China, was tested in this study. The representativeness of the present results remains unevaluated carefully with, for example, comparisons between vehicles to achieve broader statistical results, although the tests in the present studies were conducted under strict control conditions.

\section{Results}

\subsection{Particle morphology, elemental composition, and size}

A total of 2880 particles were analysed from the GDI-engine vehicles. Most of the particles were in the submicron size range. Based on morphology and elemental composition of the particles, the majority of them were identified as soot, organic, and Ca-rich particles; a smaller number were identified as S-rich or metal-rich particles (Fig. 1). The method of particle classification is similar to that adopted by Okada et al. (2005) and Xing et al. (2019). In the following description, " $X$-rich" means that the element $X$ occupies the largest proportion in the element composition of the particles. Figure 2 illustrates the number-size distributions of the relative concentration $(\mathrm{d} N / \mathrm{d} \log D)$ of primary particles from the GDI-engine vehicle, where $N$ is the relative number fraction and $D$ is the equivalent diameter. The particles were in the range of $60-2500 \mathrm{~nm}$ and displayed a bimodal distribution, with one mode in the 140-240 nm range and another in the $800-900 \mathrm{~nm}$ range. Particles smaller than $250 \mathrm{~nm}$ were largely underestimated because of the loss during the particle collection. Therefore, there should have been more particles in the smaller mode range than shown in Fig. 2. Concerning the loss of small particles, we measured the size distribution by the DMS500 (Fig. S2). The results showed that a large number of nucleation mode particles were emitted by the GDI vehicle.

It should be noted that organic particles were mainly composed of $\mathrm{C}$ and $\mathrm{O}$ elements and contained a small amount of the inorganic elements $\mathrm{Ca}, \mathrm{P}, \mathrm{S}$, and $\mathrm{Zn}$. Elemental mapping of the organic particles exhibited the presence of $\mathrm{Ca}, \mathrm{P}, \mathrm{S}$, and $\mathrm{Zn}$ in some of the particles, showing the mixture state of organic and inorganic materials (Fig. 1f). It has been reported that such particles could be related to the combustion of fuels or lubrication oil (Rönkkö et al., 2013). In addition to these primary organic particles, the GDI-engine vehicle emitted precursor gases, which produced secondary organic particles via gas-phase reactions and multiphase and heterogeneous processes on the primary particles. A group of spherical particles were found in the environmental chamber (Fig. 1g). These particles became semi-transparent or transparent to an electron beam, which was characteristic of organic materials, liquid water, or their evaporation residues either mixed or not mixed with electron-absorptive materials. We regarded these particles as secondary organic particles because the humidity in the chamber during the experiment was kept much below saturation (relative humidity of around $50 \%$ ). Therefore, these particles were expected to mainly consist of secondary organic materials, which should have been produced via gas-phase reactions or on the surface of pre-existing particles (Hu et al., 2016). No other elements, except $\mathrm{C}$ and $\mathrm{O}$, were identified in these particles, which was consistent with the above inference. Similar particles were also encountered 


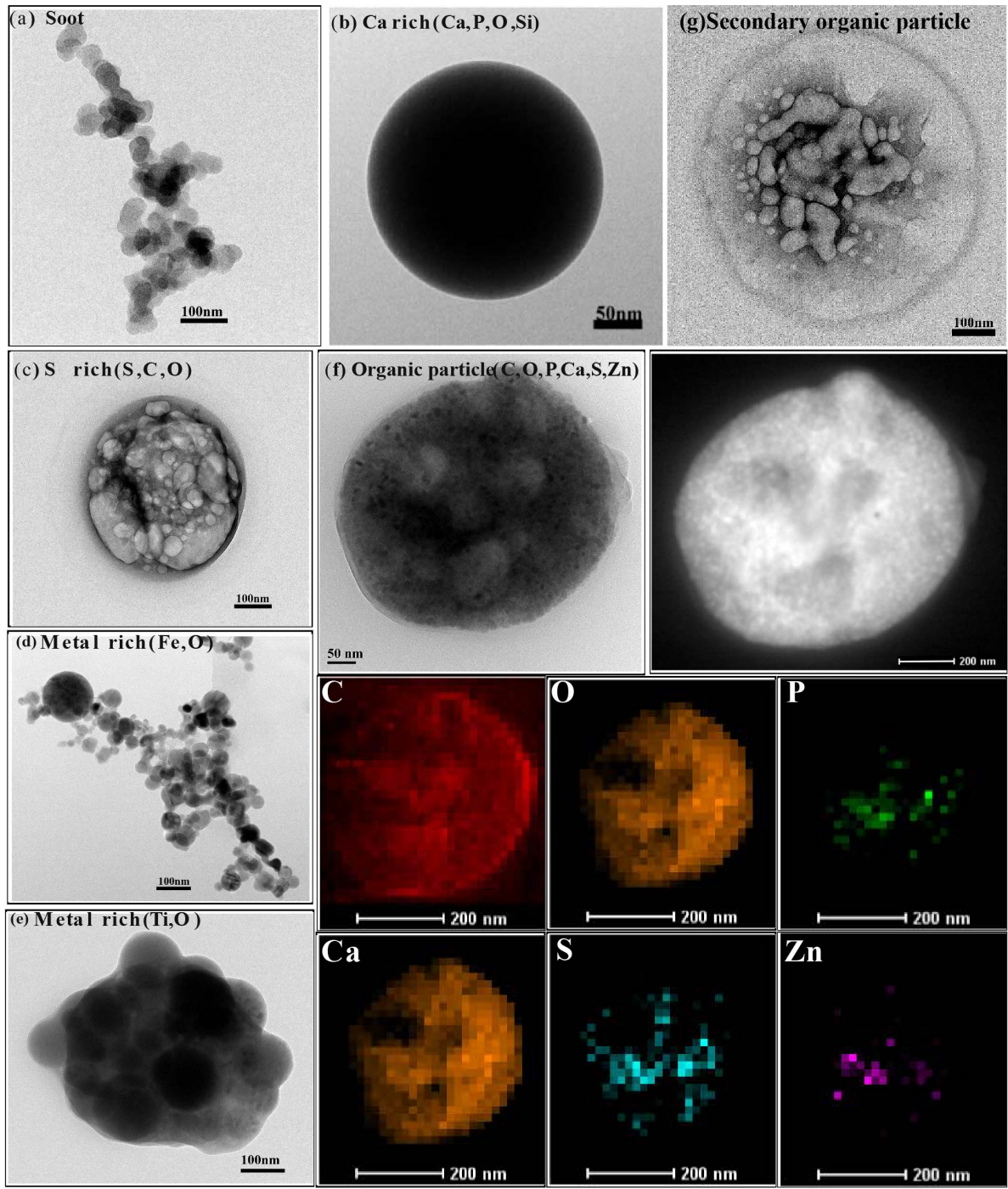

Figure 1. TEM images of the individual primary particles emitted from the GDI-engine vehicle and the secondary organic particle in the chamber after exposure to ambient sunlight for $3.5 \mathrm{~h}$. (a) Soot particle. (b) Ca-rich particle. (c) S-rich particles. (d) Metal-rich particles (Fe). (e) Metal-rich particles (Ti). (f) Bright-field-TEM and dark-field-TEM image of organic particles, and others are the mapping of the C, O, $\mathrm{P}$, $\mathrm{Ca}, \mathrm{S}$, and $\mathrm{Zn}$ in the organic particle. (g) Secondary organic particle in chamber.

in other environmental-chamber experiments studying emissions from light-duty gasoline vehicles (Jathar et al., 2014).

\subsection{Number fractions of particles}

Figure 3 illustrates the numbers of accumulation mode particles emitted by burning $1 \mathrm{~kg}$ of fuel during the cold-start and hot-start driving cycles. PM emissions at the start-up stage under both cold and hot-start states were higher than the emissions under the states when the engine was fully warmed and the vehicle operation was stabilized. The PM emission was the highest under the hot stabilized running state $\left(2.3 \times 10^{10}\right.$ particles per $\mathrm{kg}$ fuel $)$, followed by those under the hot-start $\left(1.2 \times 10^{10}\right.$ particles per $\mathrm{kg}$ fuel), cold-start $\left(7.1 \times 10^{9}\right.$ particles per $\mathrm{kg}$ fuel), and acceleration running states $\left(2.9 \times 10^{9}\right.$ particles per $\mathrm{kg}$ fuel $)$, with the emissions under the idle state being the lowest $\left(7.4 \times 10^{8}\right.$ particles per $\mathrm{kg}$ fuel; Fig. S3). The higher emissions of particles in terms of number for the GDI vehicle under the hot-start state can be ascribed to the experimental time of the vehicle engine. The hot-start test in this study was conducted within $5 \mathrm{~min}$ of the cold-start test. The PM emissions from GDI vehicles were less affected by ambient temperature for the initial $30 \mathrm{~min}$ during the warming up of the engines (Cotte et al., 2001). This may lead to the high value of the PM emission for the hot-start state, which is slightly higher than that for the coldstart state. Although the total PM emissions were higher under the hot-start state than those under the cold-start state, the comparison of those in the size range of the accumulation 


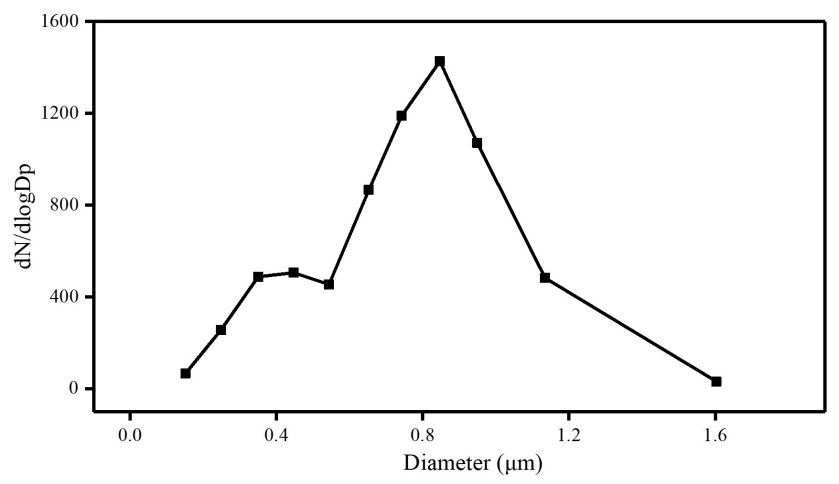

Figure 2. Size distribution of analysed particles emitted from the GDI-engine vehicles by the TEM images. In total, 2880 particles were analysed from the GDI-engine vehicles. Particles smaller than $0.25 \mu \mathrm{m}$ should have been underestimated because of the collection efficiency of the impactor.

mode indicates that the particulate emissions for this mode of particles were higher under the cold-start state than under the hot-start sate (Fig. 3). This can be attributed to the lower efficiency of the vaporization of fuel droplets in the combustion cylinder under the cold-start state (Chen et al., 2017). Size distributions of the particles varied with driving conditions (Fig. S4). Under the cold-start state and acceleration running state, higher number concentrations and thus higher mass concentrations of the particles with the accumulation mode were emitted in comparison with other running states.

Under all the running states, morphologies and types of the particles remained similar but the proportions of different types of particles differed considerably (Fig. S5). The proportion of organic particles was high under hot stabilized and hot-start states. Soot particles were abundant under coldstart and acceleration states. A higher proportion of $\mathrm{Ca}$-rich particles was found under the idle state compared to those under other running states.

We estimated the number of different types of particles in the emission under the running states by burning $1 \mathrm{~kg}$ of fuel (Fig. 4). Organic particles in the emission under the hot stabilized running state $\left(2.3 \times 10^{9}\right.$ particles per $\mathrm{kg}$ fuel $)$ and the hot-start running state $\left(3.6 \times 10^{8}\right.$ particles per $\mathrm{kg}$ fuel $)$ were higher than in the emission under other running states. The number of soot particles was higher under the hot stabilized running state $\left(1.7 \times 10^{9}\right.$ particles per $\mathrm{kg}$ fuel $)$ and the coldstart state $\left(5.9 \times 10^{8}\right.$ particles per $\mathrm{kg}$ fuel $)$ than those under other running states. Under the idle state, the relative proportion of $\mathrm{Ca}$-rich particles was the highest, although their absolute number was low $\left(1.4 \times 10^{9}\right.$ particles per $\mathrm{kg}$ fuel).

Under the cold-start state, a significant proportion of the emitted particles were soot particles. This can be attributed to the incomplete vaporization of fuel droplets in the combustion cylinder (Chen et al., 2017). Under the hot-start state and the hot stabilized running state, organic particles were predominant. Under these two running states, the engine temper- ature was high, which enabled the fuel to evaporate and mix with the air easily. With the increase in the temperature in the cylinders, the rate of particle oxidation increased, which could cause an increase in organic particles in the emission (Fu et al., 2014). Under the idle state, the fuel consumption was much lower than that under the other running states, which resulted in a higher relative contribution to particles from lubricant oil. The high $\mathrm{Ca}$ content in the lubricant oil led to a higher $\mathrm{Ca}$-rich particle emission under this running state. Under the acceleration state, the predominant types of particles included soot, organic, and $\mathrm{Ca}$-rich particles. As the acceleration running required a high vehicular speed and engine load, the emissions contained more soot particles than those under other running states.

\subsection{Aged particles in the environmental chamber}

A large number of secondary organic particles (accounting for $80 \%-85 \%$ in number), some soot particles, Ca-rich particles, and primary organic particles were detected in the environmental chamber (Fig. 5). After the ageing process, many soot particles changed into core-shell structures and became coated with secondary species (Fig. 5b and c). The EDX results showed that almost all coatings were mainly composed of $\mathrm{C}, \mathrm{O}$, and $\mathrm{S}$, suggesting that these coatings were a mixture of organic and sulfate. The morphology and compositions of Ca-rich particles and organic particles (Fig. 5e and g) changed, with the aged ones having a more irregular shape and higher sulfur content in comparison with fresh ones (Fig. 5A and B).

Approximately $80 \%$ of the soot particles were present in core-shell structures and coated with secondary species after the $3.5 \mathrm{~h}$ ageing. In contrast, before the ageing, the particles with a core-shell structure were only about $10 \%$ of the total. The mean diameter of the soot particles after ageing was around $0.49 \mu \mathrm{m}$, which was much smaller than that before the ageing $(0.65 \mu \mathrm{m})$, indicating the shrinkage of the soot particles during the ageing (Fig. 5b). The core-shell ratios, defined as the ratio of the diameter of the core part $\left(D_{\text {core }}\right)$ to the diameter of the whole particle ( $D_{\text {shell }}$; Niu et al., 2016b; Hou et al., 2018), were used to quantify the ageing degree of the soot particles with coating. It was found that the core-shell ratios of the soot particles in the smog chamber were mainly in the range of $0.25-0.78$, indicating the stronger ageing degree of soot particles in the chamber than case data in urban air with the ratios of $0.4-0.9$ (Niu et al., 2016b).

\section{Discussion}

\subsection{Contribution of GDI-engine vehicle emissions to urban air pollution}

Our investigation showed that the GDI-engine vehicle emitted a large number of organic (32\%), soot (32\%), Ca-rich $(26 \%)$, S-rich $(5 \%)$, and metal-containing particles $(4 \%)$. 

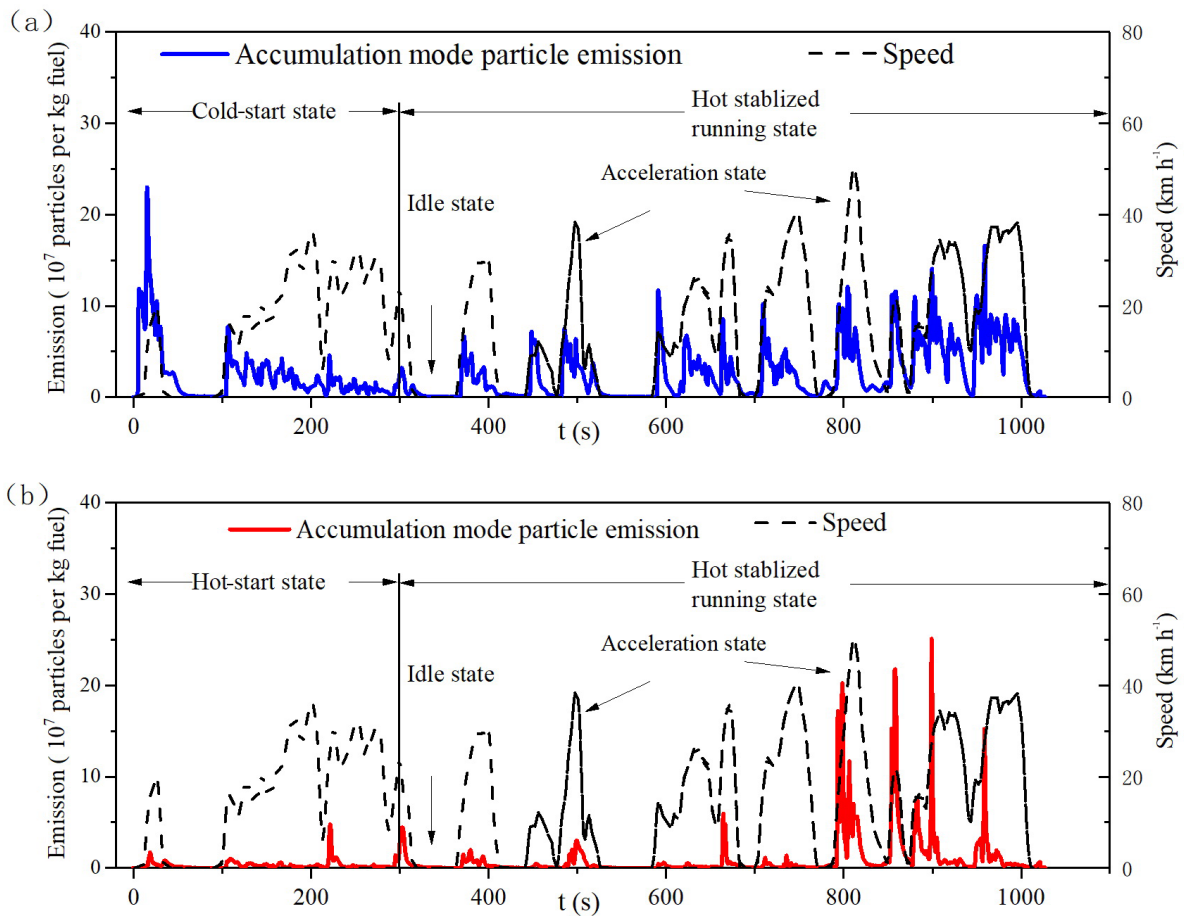

Figure 3. Particles in accumulation mode from the GDI vehicle during cold-start (a) and hot-start (b) driving cycle. The vehicle speed is also shown for reference. Before the test with cold start, the temperatures of the engine coolant and oil could not differ by more than $2{ }^{\circ} \mathrm{C}$ during the soak temperature. The hot-start test was conducted within 5 min of the cold-start test. The number concentration of particles during the tests was monitored by DMS 500.

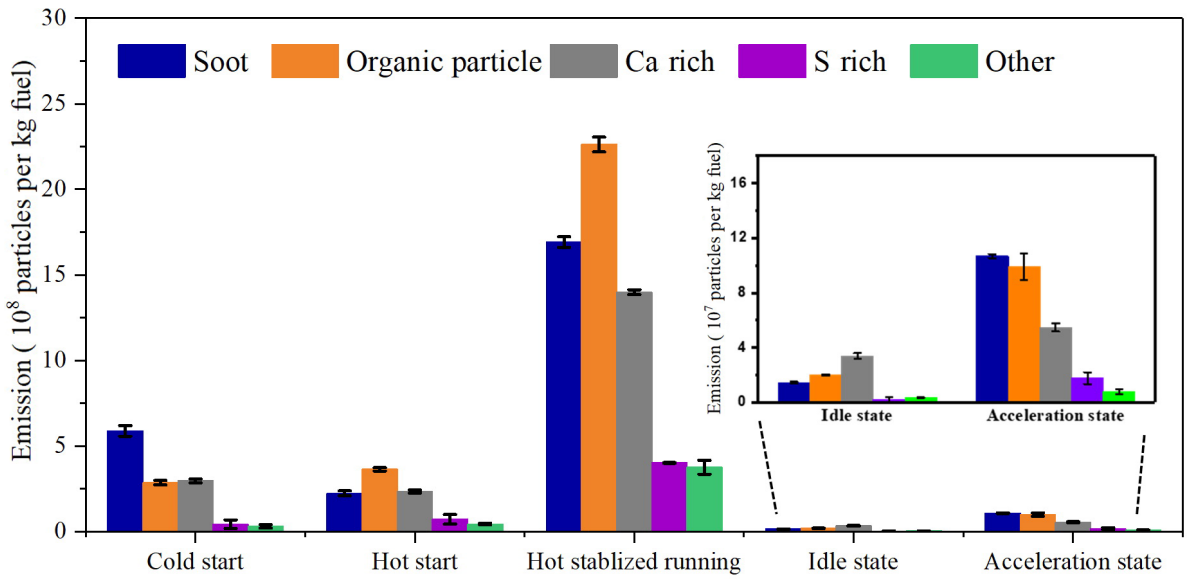

Figure 4. The number of different types of particles in the emissions from the GDI vehicle under the different running states by the burning per unit of fuel, including cold-start, hot-start, hot stabilized, idle, and acceleration states. Data presented as mean \pm standard deviation, $N=3$.

Relevant studies have also shown that the primary carbonaceous aerosols (element carbon plus primary organic aerosol - POA) accounted for $85 \%$ of the PM in the GDI vehicles, suggesting that carbonaceous aerosols were the major contributors in the PM from GDI vehicles (Du et al., 2018). Considering the large fraction of the vehicles equipped with GDI engines in megacities like Beijing, this indicates a pos- sible substantial contribution of GDI-engine vehicles to urban air pollution. Moreover, organic particles constituted the majority of the particles emitted under hot stabilized running and hot-start states. It has been noted that the organic matter was the major component of the total particle mass during the hot-start conditions (Fushimi et al., 2016; Chen et al., 2017), which was consistent with the results obtained for the 

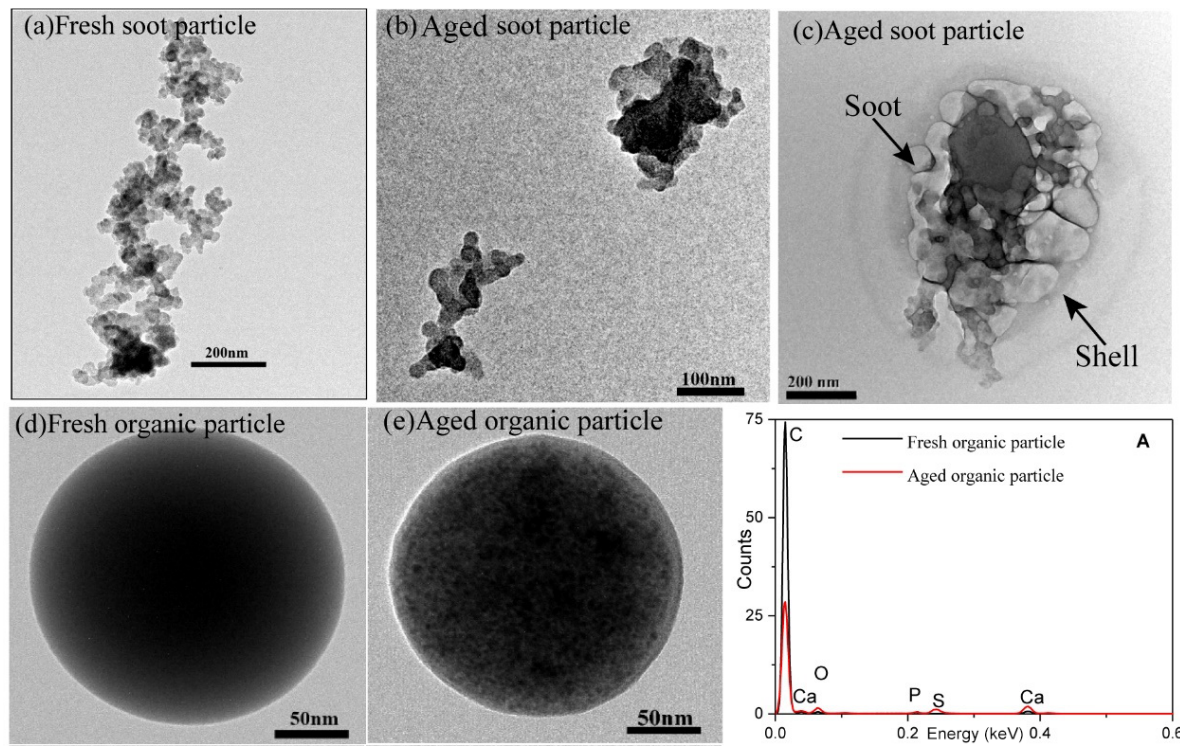

(e)Aged organic particle
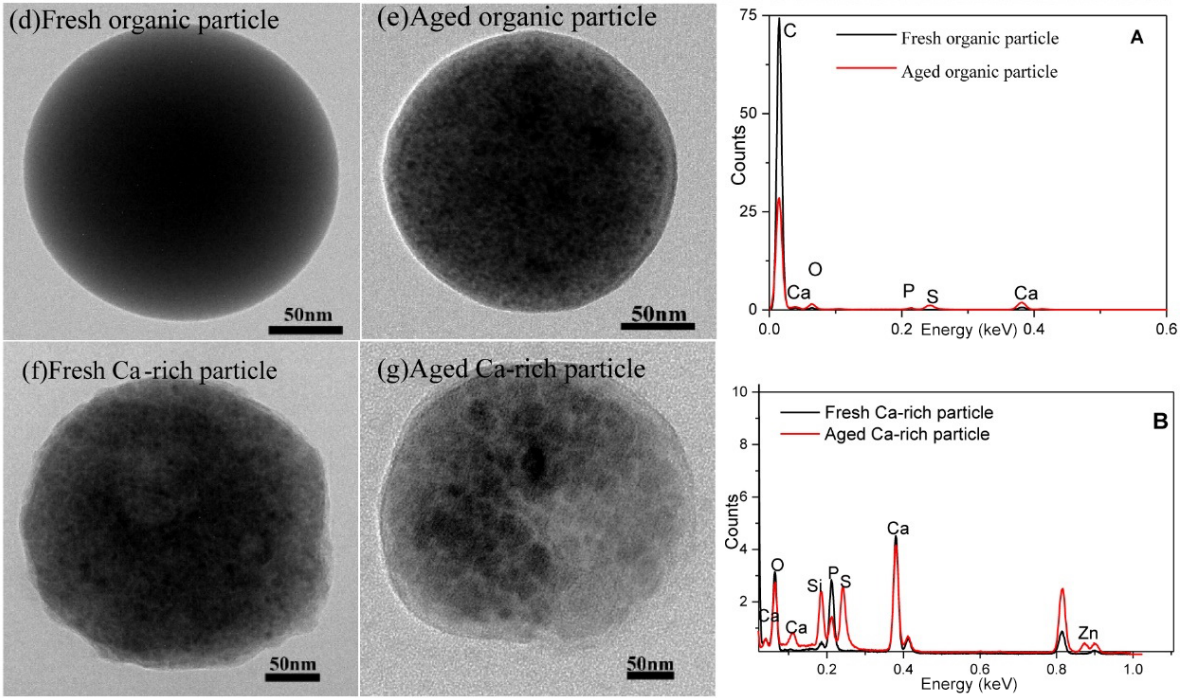

(g)Aged Carrich particle
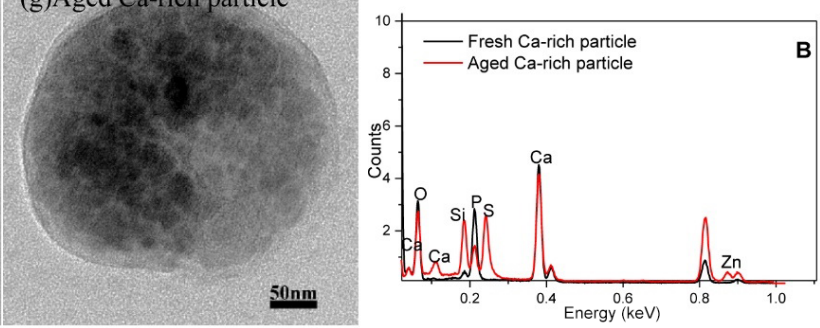

Figure 5. TEM images of particles in the chamber after exposure to ambient sunlight for $3.5 \mathrm{~h}$. (a) Fresh soot particles. (b) Aged soot particles. (c) Aged soot particle. (d) Fresh organic particle. (e) Aged organic particle. (f) Fresh Ca-rich particle. (g) Aged Ca-rich particle. (A) EDX spectrum for a fresh organic particle and an aged organic particle. (B) EDX spectrum for a fresh organic particle and an aged Ca-rich particle.

number concentrations in our study. The hot stabilized running state is the most frequent running condition of vehicles, whereas the hot-start state is the most frequent condition in congested traffic. This suggests that a substantial number of organic compounds in the air pollution of populated cities might be directly related to vehicle emissions.

Organic particles and soot particles in ambient air are emitted from a range of sources, including fossil fuels, biomass burning, and urban-waste burning (Kanakidou et al., 2005). Table 1 shows the major characteristics of particles in the emissions from different sources. For instance, there is a higher fraction of soot particles and a lower fraction of organic particles in the emissions of GDI-engine vehicles compared to PFI-engine vehicles (Xing et al., 2017). Organic particles in emissions from gasoline vehicles are usually enriched in $\mathrm{Ca}$, S, and P (Xing et al., 2017; Liati et al., 2018). In comparison, emissions from biomass or wood burning are usually dominated by organic particles, which account for more than $50 \%$ of the total number of particles (Liu et al., 2017). Furthermore, organic particles from biomass or wood burning usually show elevated $\mathrm{K}$ content, and, thus, this element is frequently used as an indicator for biomass- or wood-burning organic particles (Niu et al., 2016a). Observations of primary particles directly from coal burning have also demonstrated a predominance of organic particles, soot particles, S-rich particles, and mineral particles (Zhang et al., 2018; Wang et al., 2019). Both biomass burning and coal combustion can produce organic particles, and almost all of the emitted particles contain a certain amount of $\mathrm{Si}$ in addition to $\mathrm{C}$ and $\mathrm{O}$. Table 1 also shows the elemental concentrations in the organic particles in the emissions from different types of sources. Since the concentrations of minor elements in the organic particles are highly dependent on the sources, they could be used for source identification of individual particles in the atmosphere.

The present data also permit the compilation of a rough inventory of particle categories and amounts emitted from GDI-engine vehicles under various running conditions (Fig. 4). Combined with statistics on the number of vehicles with GDI engines, the running time, and the running conditions on roads within a certain area, it is possible to make an approximate estimate of the numbers of primary particles emitted from GDI-engine vehicles. Such an estimate is the basis for accurate source apportionment of particles from ve- 
Table 1. Comparison of chemical components between various sources, including fossil fuels, biomass burning, and urban-waste burning.

\begin{tabular}{|c|c|c|c|}
\hline Study & Source & Particle of type and relative percentages & $\begin{array}{l}\text { Chemical composition of } \\
\text { organic particles }\end{array}$ \\
\hline This study & $\begin{array}{l}\text { GDI-engine } \\
\text { vehicles }\end{array}$ & $\begin{array}{l}\text { Organic (OM; } 32 \%) \text {, } \\
\text { soot }(32 \%), \text { Ca-rich }(26 \%), \\
\text { S-rich }(5 \%), \text { metal-containing } \\
\text { particles }(4 \%)\end{array}$ & $\begin{array}{l}\text { OM with } \mathrm{Ca} \text { and } \\
\text { weak } \mathrm{P}, \mathrm{S} \text {, and } \mathrm{Zn}\end{array}$ \\
\hline Xing et al. (2019) & $\begin{array}{l}\text { PFI-engine } \\
\text { vehicles }\end{array}$ & $\begin{array}{l}\text { OM }(44 \%), \text { soot }(23 \%), \\
\text { Ca-rich }(20 \%), \text { S-rich }(6 \%), \\
\text { metal-containing particles }(6 \%)\end{array}$ & $\begin{array}{l}\text { OM with } \mathrm{Ca} \text { and } \\
\text { weak } \mathrm{P}, \mathrm{S} \text {, and } \mathrm{Zn}\end{array}$ \\
\hline Liati et al. (2018) & $\begin{array}{l}\text { GDI, PFI, } \\
\text { and diesel vehicles }\end{array}$ & $\begin{array}{l}\text { Soot, OM (called ash-bearing } \\
\text { soot particles), ash particles }\end{array}$ & $\begin{array}{l}\mathrm{OM} \text { with } \mathrm{Ca}, \mathrm{S}, \\
\mathrm{P}, \mathrm{Fe} \text {, and minor } \mathrm{Zn}\end{array}$ \\
\hline Liu et al. (2017) & $\begin{array}{l}\text { Crop residue } \\
\text { combustion }\end{array}$ & $\begin{array}{l}\text { OM }(27 \%), \text { OM-K (43\%), } \\
\text { OM-soot-K (27\%), soot-OM (3\%) }\end{array}$ & $\begin{array}{l}\text { OM particles } \\
\text { with } \mathrm{K} \text { content }\end{array}$ \\
\hline Liu et al. (2017) & $\begin{array}{l}\text { Wood } \\
\text { combustion }\end{array}$ & $\begin{array}{l}\text { OM }(16 \%), \text { soot }(18 \%) \\
\text { OM-K }(22 \%), \text { OM-soot-K }(15 \%) \\
\text { soot-OM }(29 \%)\end{array}$ & $\begin{array}{l}\text { OM particles with } \\
\text { K content }\end{array}$ \\
\hline Wang et al. (2019) & Coal burning & $\begin{array}{l}\text { OM }(38 \%), \text { soot }(40 \%), \\
\text { S-rich }(2 \%), \text { mineral } \\
\text { particles }(18 \%)\end{array}$ & $\begin{array}{l}\text { OM mainly consisting } \\
\text { of } \mathrm{C}, \mathrm{O} \text {, and } \mathrm{Si}\end{array}$ \\
\hline Zhang et al. (2018) & $\begin{array}{l}\text { Residential coal } \\
\text { burning }\end{array}$ & $\begin{array}{l}\text { OM }(51 \%), \text { OM-S }(24 \%), \\
\text { soot-OM }(23 \%), \text { S-rich }(1 \%), \\
\text { metal-rich }(1 \%), \text { mineral } \\
\text { particles }(1 \%)\end{array}$ & $\begin{array}{l}\text { OM containing } \mathrm{C}, \mathrm{O} \text {, and } \mathrm{Si} \text { with } \\
\text { minor amounts of } \mathrm{S} \text { and } \mathrm{Cl}\end{array}$ \\
\hline
\end{tabular}

hicles, and it will be very beneficial for studies on the anthropogenic sources of primary particles in urban air. These data could be brought together to better understand the sources of air pollutants in the Beijing megacity and to improve the capability of developing cost-effective mitigation measures.

\subsection{Rapid ageing of primary particles in Beijing}

The results of chamber experiments indicate that sulfate and secondary organic aerosol (SOA) form on the surface of soot, Ca-rich, and organic particles. Moreover, the atmospheric transformation of primary particles emitted by the GDI-engine vehicles could occur within $3.5 \mathrm{~h}$, indicating that the ageing was rapid. Peng et al. (2014) found similar timescales for black-carbon transformation under polluted conditions in Beijing. The rapid ageing of primary particles could be caused by several factors, such as the concentration of gaseous pollutants from the vehicles, strength of solar radiation, relative humidity $(\mathrm{RH})$, and $\mathrm{O}_{3}$ concentration (Guo et al., 2012; Deng et al., 2017; Du et al., 2018). The present experiments were conducted in the atmosphere with relative humidity of approximately $50 \%$ and solar radiation of $318 \mathrm{~W} \mathrm{~m}^{-2}$. The total hydrocarbon emission (THC) from the GDI vehicles was $0.297 \mathrm{~g} \mathrm{~km}^{-1}$. Repeated braking and acceleration in the BDC could cause incomplete combustion and consequently high THC emission. Under a high concentration of gaseous pollutants, primary particles would age rapidly when exposed to solar radiation. Consequently, secondary species including SOA and sulfate were produced on or condensed onto the particles, leading to the coating. Guo et al. (2014) also showed that secondary photochemical growth of fine aerosols during the initial stage of haze development could be attributed to highly elevated levels of gaseous pollutants.

The mixture of SOA and sulfate has been detected in our chamber experiment, indicating the involvement of inorganic salts in the SOA formation. Previous studies have demonstrated the enhancement of SOA production in the presence of inorganic sulfate (Beardsley and Jang, 2016; Kuwata et al., 2015), and this is because sulfate can catalyse carbonyl heterogeneous reactions and, consequently, lead to SOA production (Jang et al., 2002, 2004). Moreover, these aged primary particles favoured the formation of secondary aerosols by providing reaction sites and reaction catalysts. Sulfate and secondary organic aerosol (SOA) co-existed on the surface of primary particles, such as soot, Ca-rich, and organic particles. In addition, the products of VOC (volatile organic carbon) oxidation could react with $\mathrm{SO}_{2}$ to rapidly produce sulfate (Mauldin et al., 2012). Thus, the rapid ageing of primary particles could also be attributable to the acid-catalysed mechanism. As the major source of pollutants in urban air, the GDI-engine vehicles supply both primary particles and 
precursor gaseous species, and the rapid ageing of the particles under certain conditions is very likely to be the major driving force for the elevation of urban air pollution.

\subsection{Implications and perspectives}

Our results indicated that GDI-engine vehicles emitted a large amount of both primary and secondary organic aerosol. PM number emissions of organic particles from GDI-engine vehicle were $2.9 \times 10^{9}$ particles per $\mathrm{kg}$ fuel during the BDC. Secondary organic particles were predominant in the secondary aerosols, accounting for $80 \%-85 \%$ of particles in the chamber. Organic aerosol (OA) plays an important role in the Earth's radiation balance not only for its absorption and scattering of solar radiation but also because it can alter the microphysical properties of clouds (Scott et al., 2014). Particle size, shape, mixing state, and composition affect its light scatterings, absorption cross sections, and cloud condensation nuclei activity (Jacobson, 2001). OA is composed of various types of chemical compounds with varying absorption properties (mixing state), which are determined by the emission sources, the formation mechanism (Zhu et al., 2017), and the source regions (Laskin et al., 2015). Primary OA from biomass burning is co-emitted with soot (black carbon), inorganic salts, and fly ash, producing internally and externally mixed particles in which the organic components are present in different relative abundance (Lack et al., 2012). Similarly, primary OA in the exhaust of gasoline and diesel vehicles is mixed with $\mathrm{Ca}, \mathrm{P}, \mathrm{Mg}, \mathrm{Zn}, \mathrm{Fe}, \mathrm{S}$, and minor $\mathrm{Sn}$ inorganic compounds (Liati et al., 2018). In addition, previous measurements have indicated that SOA usually exists as an internal mixture with other aerosols, such as sulfate, ammonium, or nitrate (Zhu et al., 2017). Our results showed that the POA emitted from GDI-engine vehicles was mixed with soot and inorganic components such as $\mathrm{Ca}, \mathrm{P}$, and $\mathrm{Zn}$. Some of the SOA formed in the smog chamber was mixed with sulfate. The complexity of the mixing state makes it difficult to characterize the properties of OA. Lang-Yona et al. (2010) have found that for aerosols consisting of a strongly absorbing core coated by a non-absorbing shell, the Mie theory prediction deviates from the measurements by up to $10 \%$. Moreover, the atmospheric ageing process, involving aqueousphase ageing and atmospheric oxidation, can either enhance or reduce light absorption by OA (Bones et al., 2010). The condensation process may result in a dramatic enhancement of hydrolysis of OA compounds, affecting their absorption spectra (Lambe et al., 2015).

Our results also showed that POA emitted by GDI-engine vehicles could acquire $\mathrm{OA}$ and sulfate coatings rapidly, within a few hours, and increase a sizable fraction of total ambient aerosols existing as internal mixtures. In addition, the fast ageing further caused the increase in aged POA in the total OA; this consequently largely modified the properties of the particles such as their optical properties. The results of the experiments in the chamber showed that most of the aged POA had a core-shell structure, whereas most of the SOA produced by gas-phase reactions had a uniform structure. These results push forward the understanding on the mixing state and chemical composition of both POA and SOA. The experimental data will benefit the parameterization of vehicles emissions in numerical models dealing with urban air pollution.

\section{Conclusions}

Five types of individual particles emitted by a GDI-engine vehicle were identified, including soot, organic, Ca-rich, Srich, and metal-rich particles. Among them, soot, organic, and Ca-rich particles were predominant. The particles emitted from this commercial GDI-engine vehicle displayed a bimodal size distribution.

The concentrations of the particles emitted by this commercial GDI-engine vehicle vary with different running conditions. The PM emission was the highest under the hot stabilized running state, followed by those under the hot-start, cold-start, and acceleration running states, with the emission under the idle state being the lowest.

The relative proportions of the different types of particles emitted by this commercial GDI-engine vehicle varied with different running conditions. Large numbers of organic particles were emitted during hot stabilized and hot-start states. Under cold-start and acceleration states, the emissions were enriched in soot particles. Under the idle state, a higher number of Ca-rich particles were emitted, although the absolute number was low.

After ageing in the environmental chamber, the structure of the soot particles changed into a core-shell structure, and the particles were coated with condensed secondary organic material. Ca-rich particles and organic particles were also modified, and their content of sulfur increased after ageing.

Ageing of the emitted particles occurred rapidly, within hours. Such rapid ageing could be attributable to an acidcatalysed mechanism and to the high initial concentrations of gaseous pollutants emitted by this commercial GDI-engine vehicle.

Data availability. All data presented in this paper are available upon request. Please contact the corresponding author (shaol@cumtb.edu.cn).

Supplement. The supplement related to this article is available online at: https://doi.org/10.5194/acp-20-2781-2020-supplement.

Author contributions. LS designed this study; JX performed the experiments. JX, LS, and DZ summarized the data and wrote the paper. WZ, JP, WW, SS, and MH supported the experiments and commented on the paper. 
Competing interests. The authors declare that they have no conflict of interest.

Special issue statement. This article is part of the special issue "In-depth study of air pollution sources and processes within Beijing and its surrounding region (APHH-Beijing) (ACP/AMT interjournal SI)". It is not associated with a conference.

Acknowledgements. The data analysis was partly supported by the Science and Technology Project funded by the Education Department of Jiangxi Province (no. GJJ180226), the Open Foundation of the Jiangxi Province Key Laboratory of the Causes and Control of Atmospheric Pollution, the East China University of Technology (no. AE1902), the Yue Qi Scholar Fund of China University of Mining and Technology (Beijing), and a Grant-in-Aid for Scientific Research (B) (no. 16H02942) from the JSPS.

Financial support. This research has been supported by the Projects of International Cooperation and Exchanges of the NSFC (grant no. 41571130031).

Review statement. This paper was edited by James Allan and reviewed by two anonymous referees.

\section{References}

Adachi, K. and Buseck, P. R.: Changes in shape and composition of sea-salt particles upon aging in an urban atmosphere, Atmos. Environ., 100, 1-9, https://doi.org/10.1016/j.atmosenv.2014.10.036, 2015.

Alves, C. A., Lopes, D. J., Calvo, A. I., Evtyugina, M., Rocha, S., and Nunes, T.: Emissions from light-duty diesel and gasoline in-use vehicles measured on chassis dynamometer test cycles, Aerosol Air Qual. Res., 15, 99-116, https://doi.org/10.4209/aaqr.2014.01.0006, 2015.

Baral, B., Raine, R., and Miskelly, G.: Effect of engine operating conditions on spark-ignition engine PAH emissions, SAE Technical Paper 2011-01-1161, https://doi.org/10.4271/2011-011161, 2011.

Beardsley, R. L. and Jang, M.: Simulating the SOA formation of isoprene from partitioning and aerosol phase reactions in the presence of inorganics, Atmos. Chem. Phys., 16, 5993-6009, https://doi.org/10.5194/acp-16-5993-2016, 2016.

Bond, T. C., Doherty, S. J., Fahey, D. W., Forster, P. M., Berntsen, T., DeAngelo, B. J., Flanner, M. G., Ghan, S., Kärcher, B., Koch, D., Kinne, S., Kondo, Y., Quinn, P. K., Sarofim, M. C., Schultz, M. G., Schulz, M., Venkataraman, C., Zhang, H., Zhang, S., Bellouin, N., Guttikunda, S. K., Hopke, P. K., Jacobson, M. Z., Kaiser, J. W., Klimont, Z., Lohmann, U., Schwarz, J. P., Shindell, D., Storelvmo, T., Warren, S. G., and Zender, C. S.: Bounding the role of black carbon in the climate system: A scientific assessment, J. Geophys. Res.-Atmos., 118, 5380-5552, https://doi.org/10.1002/jgrd.50171, 2013.
Bones, D. L., Henricksen, D. K., Mang, S. A., Gonsior, M., Bateman, A. P., Nguyen, T. B., Cooper, W. J., and Nizkorodov, S. A.: Appearance of strong absorbers and fluorophores in limonene$\mathrm{O}_{3}$ secondary organic aerosol due to $\mathrm{NH}^{4+}$-mediated chemical aging over long time scales, J. Geophys. Res., 115, D05203, https://doi.org/10.1029/2009JD012864, 2010.

Chang, L., Shao, L., Yang, S., Li, J., Zhang, M., Feng, X., and Li, Y.: Study on variation characteristics of $\mathrm{PM}_{2.5}$ mass concentrations in Beijing after the action for comprehensive control of air pollution, Journal of Mining Science and Technology, 4, 539546, https://doi.org/10.19606/j.cnki.jmst.2019.06.009, 2019 (in Chinese with English Abstract).

Chart-asa, C. and Gibson, J. M.: Health impact assessment of traffic-related air pollution at the urban project scale: Influence of variability and uncertainty, Sci. Total Environ., 506-507, 409421, https://doi.org/10.1016/j.scitotenv.2014.11.020, 2015.

Chen, L. and Stone, R.: Measurement of enthalpies of vaporization of isooctane and ethanol blends and their effects on PM emissions from a GDI engine, Energ. Fuel, 25, 1254-1259, https://doi.org/10.1021/ef1015796, 2011.

Chen, L., Liang, Z., Zhang, X., and Shuai, S.: Characterizing particulate matter emissions from GDI and PFI vehicles under transient and cold start conditions, Fuel, 189, 131-140, https://doi.org/10.1016/j.fuel.2016.10.055, 2017.

Chen, Z., Chen, D., Xie, X., Cai, J., Zhuang, Y., Cheng, N., He, B., and Gao, B.: Spatial self-aggregation effects and national division of city-level $\mathrm{PM}_{2.5}$ concentrations in China based on spatio-temporal clustering, J. Clean. Prod., 207, 875-881, https://doi.org/10.1016/j.jclepro.2018.10.080, 2019.

Cotte, H., Bessagnet, B., Blondeau, C., Mallet-Hubert, P. Y., Momique, J. C., Walter, C., Boulanger, L., Deleger, D., Jouvenot, G., Pain, C., and Rouveirolles, P.: Cold-start emissions from petrol and diesel vehicles according to the emissions regulations (from Euro 92 to Euro 2000), Int. J. Vehicle Des., 27 275-285, https://doi.org/10.1504/IJVD.2001.001971, 2001.

Deng, W., Hu, Q., Liu, T., Wang, X., Zhang, Y., Song, W., Sun, Y., Bi, X., Yu, J., Yang, W., Huang, X., Zhang, Z., Huang, Z., He, Q., Mellouki, A., and George, C.: Primary particulate emissions and secondary organic aerosol (SOA) formation from idling diesel vehicle exhaust in China, Sci. Total Environ., 593-594, 462-469, https://doi.org/10.1016/j.scitotenv.2017.03.088, 2017.

Du, Z., Hu, M., Peng, J., Zhang, W., Zheng, J., Gu, F., Qin, Y., Yang, Y., Li, M., Wu, Y., Shao, M., and Shuai, S.: Comparison of primary aerosol emission and secondary aerosol formation from gasoline direct injection and port fuel injection vehicles, Atmos. Chem. Phys., 18, 9011-9023, https://doi.org/10.5194/acp18-9011-2018, 2018.

Fu, H., Wang, Y., Li, X., and Shuai, S.: Impacts of cold-start and gasoline RON on particulate emission from vehicles powered by GDI and PFI engines, SAE Technical Paper 2014-01-2836, https://doi.org/10.4271/2014-01-2836, 2014.

Fushimi, A., Kondo, Y., Kobayashi, S., Fujitani, Y., Saitoh, K., Takami, A., and Tanabe, K.: Chemical composition and source of fine and nanoparticles from recent direct injection gasoline passenger cars: Effects of fuel and ambient temperature, Atmos. Environ., 124, 77-84, https://doi.org/10.1016/j.atmosenv.2015.11.017, 2016.

Giechaskiel, B., Maricq, M., Ntziachristos, L., Dardiotis, C., Wang, X., Axmann, H., Bergmann, A., and Schindler, W.: Review of 
motor vehicle particulate emissions sampling and measurement: From smoke and filter mass to particle number, J. Aerosol Sci., 67, 48-86, https://doi.org/10.1016/j.jaerosci.2013.09.003, 2014.

Guo, S., Hu, M., Guo, Q., Zhang, X., Zheng, M., Zheng, J., Chang, C. C., Schauer, J. J., and Zhang, R.: Primary sources and secondary formation of organic aerosols in Beijing, China, Environ. Sci. Technol., 18, 9846-9853, 2012.

Guo, S., Hu, M., Zamora, M. L., Peng, J., Shang, D., Zheng, J., Du Z, Wu, Z., Shao, M., Zeng, L., Molina, M. J., and Zhang, R.: Elucidating severe urban haze formation in China, P. Natl. Acad. Sci. USA, 111, 17373-17378, https://doi.org/10.1073/pnas.1419604111, 2014.

Hedge, M., Weber, P., Gingrich, J., Alger, T., and Khalek, I. A.: Effect of EGR on Particle Emissions from a GDI Engine, SAE Int. J. Engines, 4, 650-666, https://doi.org/10.4271/2011-01-0636, 2011.

Hou, C., Shao, L., Hu, W., Zhang, D., Zhao, C., Xing, J., Huang, X., and Hu, M.: Characteristics and aging of trafficderived particles in a highway tunnel at a coastal city in southern China, Sci. Total Environ., 619-620, 1385-1393, https://doi.org/10.1016/j.scitotenv.2017.11.165, 2018.

Hu, W., Niu, H., Zhang, D., Wu, Z., Chen, C., Wu, Y., Shang, D., and $\mathrm{Hu}, \mathrm{M}$.: Insights into a dust event transported through Beijing in spring 2012: Morphology, chemical composition and impact on surface aerosols, Sci. Total Environ., 565, 287-298, https://doi.org/10.1016/j.scitotenv.2016.04.175, 2016.

Huang, R., Zhang, Y., Bozzetti, C., Ho, K., Cao, J., Han, Y., Daellenbach, K. R., Slowik, J. G., Platt, S. M., Canonaco, F., Zotter, P., Wolf, R., Pieber, S. M., Bruns, E. A., Crippa, M., Ciarelli, G., Piazzalunga, A., Schwikowski, M., Abbaszade, G., SchnelleKreis, J., Zimmermann, R., An, Z., Szidat, S., Baltensperger, U., Haddad, I. E., and Prévôt, A. S. H.: High secondary aerosol contribution to particulate pollution during haze events in China, Nature, 514, 218-222, https://doi.org/10.1038/nature13774, 2014.

Hwa, M. and Yu, T.: Development of real-world driving cycles and estimation of emission factors for in-use light-duty gasoline vehicles in urban areas, Environ. Monit. Assess., 186, 3985-3994, https://doi.org/10.1007/s10661-014-3673-1, 2014.

Jacobson, M. Z.: Strong radiative heating due to the mixing state of black carbon in atmospheric aerosols, Nature, 409, 695-697, https://doi.org/10.1038/35055518, 2001.

Jang, M., Czoschke, N. M., and Northcross, A. L.: Atmospheric organic aerosol production by heterogeneous acid-catalyzed reactions, Chemphyschem, 5, 1647-1661, https://doi.org/10.1002/cphc.200301077, 2004.

Jang, M. S., Czoschke, N. M., Lee, S., and Kamens, R. M.: Heterogeneous atmospheric aerosol production by acidcatalyzed particle-phase reactions, Science, 298, 814-817, https://doi.org/10.1126/science.1075798, 2002.

Jathar, S. H., Gordon, T. D., Hennigan, C. J., Pye, H. O. T., Pouliot, G., Adams, P. J., Donahue, N. M., and Robinson, A. L.: Unspeciated organic emissions from combustion sources and their influence on the secondary organic aerosol budget in the United States, P. Natl. Acad. Sci. USA, 111, 10473-10478, https://doi.org/10.1073/pnas.1323740111, 2014.

Kanakidou, M., Seinfeld, J. H., Pandis, S. N., Barnes, I., Dentener, F. J., Facchini, M. C., Van Dingenen, R., Ervens, B., Nenes, A., Nielsen, C. J., Swietlicki, E., Putaud, J. P., Balkanski, Y., Fuzzi, S., Horth, J., Moortgat, G. K., Winterhalter, R., Myhre, C. E.
L., Tsigaridis, K., Vignati, E., Stephanou, E. G., and Wilson, J.: Organic aerosol and global climate modelling: a review, Atmos. Chem. Phys., 5, 1053-1123, https://doi.org/10.5194/acp-5-10532005, 2005.

Khalek, I. A., Bougher, T., and Jetter, J. J.: Particle Emissions from a 2009 gasoline direct injection engine using different commercially available fuels, SAE Int. J. Fuels Lubr., 3, 623-637, https://doi.org/10.4271/2010-01-2117, 2010.

Kuwata, M., Liu, Y., McKinney, K., and Martin, S. T.: Physical state and acidity of inorganic sulfate can regulate the production of secondary organic material from isoprene photooxidation products, Phys. Chem. Chem. Phys., 17, 5670-5678, https://doi.org/10.1039/C4CP04942J, 2015.

Lack, D. A., Langridge, J. M., Bahreini, R., Cappa, C. D., Middlebrook, A. M., and Schwarz, J. P.: Brown carbon and internal mixing in biomass burning particles, P. Natl. Acad. Sci. USA, 109, 14802-14807, 10.1073/pnas.1206575109, 2012.

Lambe, A. T., Ahern, A. T., Wright, J. P., Croasdale, D. R., Davidovits, P., and Onasch, T. B.: Oxidative aging and cloud condensation nuclei activation of laboratory combustion soot, J. Aerosol Sci., 79, 31-39, https://doi.org/10.1016/j.jaerosci.2014.10.001, 2015.

Lang-Yona, N., Abo-Riziq, A., Erlick, C., Segre, E., Trainic, M., and Rudich, Y.: Interaction of internally mixed aerosols with light, Phys. Chem. Chem. Phys., 12, 21-31, https://doi.org/10.1039/B913176K, 2010.

Laskin, A., Laskin, J., and Nizkorodov, S.A.: Chemistry of Atmospheric Brown Carbon, Chem. Rev., 115, 4335-4382, https://doi.org/10.1021/cr5006167, 2015.

Li, W. and Shao, L.: Transmission electron $\mathrm{m}$ icroscopy study of aerosol particles from the brown hazes in northern china, J. Geophys. Res.-Atmos., D09302, https://doi.org/10.1029/2008JD011285, 2009.

Liati, A., Schreiber, D., Dasilva, Y. A. R., and Eggenschwiler, P. D.: Ultrafine particle emissions from modern gasoline and diesel vehicles: An electron microscopic perspective, Environ. Pollut., 239, 661-669, https://doi.org/10.1016/j.envpol.2018.04.081, 2018.

Liu, L., Kong, S., Zhang, Y., Wang, Y., Xu, L., Yan, Q., Lingaswamy, A. P., Shi, Z., Lv, S., Niu, H., Shao, L., Hu, M., Zhang, D., Chen, J., Zhang, X., and Li, W.: Morphology, composition, and mixing state of primary particles from combustion sources - crop residue, wood, and solid waste, Sci. Rep.-UK, 5047, https://doi.org/10.1038/s41598-017-05357-2, 2017.

Loh, N. D., Hampton, C. Y., Martin, A. V., Starodub, D., Sierra, R. G., Barty, A., Aquila, A., Schulz, J., Lomb, L., Steinbrener, J., Shoeman, R. L., Kassemeyer, S., Bostedt, C., Bozek, J., Epp, S. W., Erk, B., Hartmann, R., Rolles, D., Rudenko, A., Rudek, B., Foucar, L., Kimmel, N., Weidenspointner, G., Hauser, G., Holl, P., Pedersoli, E., Liang, M., Hunter, M. M., Gumprecht, L., Coppola, N., Wunderer, C., Graafsma, H., Maia, F. R. N. C., Ekeberg, T., Hantke, M., Fleckenstein, H., Hirsemann, H., Nass, K., White, T. A., Tobias, H. J., Farquar, G. R., Benner, W. H., Hau-Riege, S. P., Reich, C., Hartmann, A., Soltau, H., Marchesini, S., Bajt, S., Barthelmess, M., Bucksbaum, P., Hodgson, K. O., Strueder, L., Ullrich, J., Frank, M., Schlichting, I., Chapman, H. N., and Bogan, M. J.: Fractal morphology, imaging and mass spectrometry of single aerosol particles in flight, Nature, 486, 513-517, https://doi.org/10.1038/nature11222, 2012. 
Lu, K. D., Hofzumahaus, A., Holland, F., Bohn, B., Brauers, T., Fuchs, H., Hu, M., Häseler, R., Kita, K., Kondo, Y., Li, X., Lou, S. R., Oebel, A., Shao, M., Zeng, L. M., Wahner, A., Zhu, T., Zhang, Y. H., and Rohrer, F.: Missing $\mathrm{OH}$ source in a suburban environment near Beijing: observed and modelled $\mathrm{OH}$ and $\mathrm{HO}_{2}$ concentrations in summer 2006, Atmos. Chem. Phys., 13, 10571080, https://doi.org/10.5194/acp-13-1057-2013, 2013.

Luo, Y., Zhu, L., Fang, J., Zhuang, Z., Guan, C., Xia, C., Xie, X., and Huang, Z.: Size distribution, chemical composition and oxidation reactivity of particulate matter from gasoline direct injection (GDI) engine fueled with ethanol-gasoline fuel, Appl. Therm. Eng., 89, 647-655, https://doi.org/10.1016/j.applthermaleng.2015.06.060, 2015.

Ma, Q., Wu, Y., Zhang, D., Wang, X., Xia, Y., Liu, X., Tian, P., Han, Z., Xia, X., Wang, Y., and Zhang, R.: Roles of regional transport and heterogeneous reactions in the $\mathrm{PM}_{2.5}$ increase during winter haze episodes in Beijing, Sci. Total Environ., 599, 246-253, https://doi.org/10.1016/j.scitotenv.2017.04.193, 2017.

Maricq, M. M., Szente, J., Loos, M., and Vogt, R.: Motor vehicle PM emissions measurement at LEV III levels, SAE Int. J. Engines, 4, 597-609, https://doi.org/10.4271/2011-01-0623, 2011.

Mauldin, R. L. I., Berndt, T., Sipilae, M., Paasonen, P., Petaja, T., Kim, S., Kurten, T., Stratmann, F., Kerminen, V., and Kulmala, M.: A new atmospherically relevant oxidant of sulphur dioxide, Nature, 488, 193-196, https://doi.org/10.1038/nature11278, 2012.

National Bureau of Statistics of China: China Statistical Yearbook 2018, part sixteen: Transportation, post and telecommunications and software industry, available at: http://www.stats.gov.cn/tjsj/ ndsj/2018/indexch.htm (last access: 31 December 2017), 2018.

Niu, H., Shao, L., and Zhang, D.: Aged status of soot particles during the passage of a weak cyclone in Beijing, Atmos. Environ., 45, 2699-2703, https://doi.org/10.1016/j.atmosenv.2011.02.056, 2011.

Niu, H., Cheng, W., Hu, W., and Pian, W.: Characteristics of individual particles in a severe short-period haze episode induced by biomass burning in Beijing, Atmos. Pollut. Res., 7, 1072-1081, https://doi.org/10.1016/j.apr.2016.05.011, 2016a.

Niu, H., Hu, W., Zhang, D., Wu, Z., and Guo, S.: Variations of fine particle physiochemical properties during a heavy haze episode in the winter of Beijing, Sci. Total Environ., 571, 103-109, https://doi.org/10.1016/j.scitotenv.2016.07.147, 2016 b.

Okada, K., Qin, Y., and Kai, K.: Elemental composition and mixing properties of atmospheric mineral particles collected in Hohhot, China, Atmos. Res., 73, 45-67, https://doi.org/10.1016/j.atmosres.2004.08.001, 2005.

Peng, J., Hu, M., Guo, S., Du, Z., Shang, D., Zheng, J., Zheng, J., Zeng, L., Shao, M., Wu, Y., Collins, D., and Zhang, R.: Ageing and hygroscopicity variation of black carbon particles in Beijing measured by a quasi-atmospheric aerosol evolution study (QUALITY) chamber, Atmos. Chem. Phys., 17, 10333-10348, https://doi.org/10.5194/acp-17-10333-2017, 2017.

Peng, J. F., Hu, M., Wang, Z. B., Huang, X. F., Kumar, P., Wu, Z. J., Guo, S., Yue, D. L., Shang, D. J., Zheng, Z., and He, L. Y.: Submicron aerosols at thirteen diversified sites in China: size distribution, new particle formation and corresponding contribution to cloud condensation nuclei production, Atmos. Chem. Phys., 14, 10249-10265, https://doi.org/10.5194/acp-14-102492014, 2014.
Petzold, A., Marsh, R., Johnson, M., Miller, M., Sevcenco, Y., Delhaye, D., Ibrahim, A., Williams, P., Bauer, H., Crayford, A., Bachalo, W. D., and Raper, D.: Evaluation of methods for measuring particulate matter emissions from gas turbines, Environ. Sci. Technol., 45, 3562-3568, 2011.

Rönkkö, T., Lähde, T., Heikkilä, J., Pirjola, L., Bauschke, U., Arnold, F., Schlager, H., Rothe, D., Yli-Ojanperä, J., and Keskinen, J.: Effects of gaseous sulphuric acid on diesel exhaust nanoparticle formation and characteristics, Environ. Sci. Technol., 47, 11882-11889, https://doi.org/10.1021/es402354y, 2013.

Scott, C. E., Rap, A., Spracklen, D. V., Forster, P. M., Carslaw, K. S., Mann, G. W., Pringle, K. J., Kivekäs, N., Kulmala, M., Lihavainen, H., and Tunved, P.: The direct and indirect radiative effects of biogenic secondary organic aerosol, Atmos. Chem. Phys., 14, 447-470, https://doi.org/10.5194/acp-14-4472014, 2014.

Shao, L., Hu, Y., Fan, J., Wang, J., Wang, J., and Ma, J.: Physicochemical characteristics of aerosol particles in the Tibetan Plateau: Insights from TEM-EDX analysis, J. Nanosci. Nanotechno., 17, 6899-6908, https://doi.org/10.1166/jnn.2017.14472, 2017a.

Shao, L., Hu, Y., Shen, R., Schäfer, K., Wang, J., Wang, J., SchnelleKreis, J., Zimmermann, R., BéruBé, K., and Suppan, P.: Seasonal variation of particle-induced oxidative potential of airborne particulate matter in Beijing, Sci. Total Environ., 579, 1152-1160, https://doi.org/10.1016/j.scitotenv.2016.11.094, 2017b.

Song, C., Na, K., Warren, B., Malloy, Q., and Cocker, D. R.: Secondary Organic Aerosol Formation from m-Xylene in the Absence of $\mathrm{NO}_{x}$, Environ. Sci. Technol., 41, 7409-7416, https://doi.org/10.1021/es070429r, 2007.

Song, M., Zhang, C., Wu, H., Mu, Y., Ma, Z., Zhang, Y., Liu, J., and $\mathrm{Li}, \mathrm{X}$.: The influence of $\mathrm{OH}$ concentration on SOA formation from isoprene photooxidation, Sci. Total Environ., 650, 951-957, https://doi.org/10.1016/j.scitotenv.2018.09.084, 2019.

Shi, Z., Vu, T., Kotthaus, S., Harrison, R. M., Grimmond, S., Yue, S., Zhu, T., Lee, J., Han, Y., Demuzere, M., Dunmore, R. E., Ren, L., Liu, D., Wang, Y., Wild, O., Allan, J., Acton, W. J., Barlow, J., Barratt, B., Beddows, D., Bloss, W. J., Calzolai, G., Carruthers, D., Carslaw, D. C., Chan, Q., Chatzidiakou, L., Chen, Y., Crilley, L., Coe, H., Dai, T., Doherty, R., Duan, F., Fu, P., Ge, B., Ge, M., Guan, D., Hamilton, J. F., He, K., Heal, M., Heard, D., Hewitt, C. N., Hollaway, M., Hu, M., Ji, D., Jiang, X., Jones, R., Kalberer, M., Kelly, F. J., Kramer, L., Langford, B., Lin, C., Lewis, A. C., Li, J., Li, W., Liu, H., Liu, J., Loh, M., Lu, K., Lucarelli, F., Mann, G., McFiggans, G., Miller, M. R., Mills, G., Monk, P., Nemitz, E., O’Connor, F., Ouyang, B., Palmer, P. I., Percival, C., Popoola, O., Reeves, C., Rickard, A. R., Shao, L., Shi, G., Spracklen, D., Stevenson, D., Sun, Y., Sun, Z., Tao, S., Tong, S., Wang, Q., Wang, W., Wang, X., Wang, X., Wang, Z., Wei, L., Whalley, L., Wu, X., Wu, Z., Xie, P., Yang, F., Zhang, Q., Zhang, Y., Zhang, Y., and Zheng, M.: Introduction to the special issue "In-depth study of air pollution sources and processes within Beijing and its surrounding region (APHH-Beijing)", Atmos. Chem. Phys., 19, 7519-7546, https://doi.org/10.5194/acp19-7519-2019, 2019.

Suarez-Bertoa, R., Zardini, A. A., Platt, S. M., Hellebust, S., Pieber, S. M., El Haddad, I., Temime-Roussel, B., Baltensperger, U., Marchand, N., Prévôt, A. S. H., and Astorga, C.: Primary emis- 
sions and secondary organic aerosol formation from the exhaust of a flex-fuel (ethanol) vehicle, Atmos. Environ., 117, 200-211, https://doi.org/10.1016/j.atmosenv.2015.07.006, 2015.

Szybist, J. P., Youngquist, A. D., Barone, T. L., Storey, J. M., and Moore, W. R.: Ethanol blends and engine operating strategy effects on light-duty spark-ignition engine particle emissions, Energ. Fuel., 25, 4977-4985, https://doi.org/10.1021/ef201127y, 2011.

Wang, W., Shao, L., Li, J., Chang, L., Zhang, D., Zhang, C., and Jiang, J.: Characteristics of individual particles emitted from an experimental burning chamber with coal from the lung cancer area of Xuanwei, China, Aerosol Air Qual. Res., 19, 355-363, https://doi.org/10.4209/aaqr.2018.05.0187, 2019.

Xing, J., Shao, L., Zheng, R., Peng, J., Wang, W., Guo, Q., Wang, Y., Qin, Y., Shuai, S., and Hu, M.: Individual particles emitted from gasoline engines: Impact of engine types, engine loads and fuel components, J. Clean. Prod., 149, 461-471, https://doi.org/10.1016/j.jclepro.2017.02.056, 2017.

Xing, J., Shao, L., Zhang, W., Peng, J., Wang, W., Hou, C., Shuai, S., Hu, M., and Zhang, D.: Morphology and composition of particles emitted from a port fuel injection gasoline vehicle under real-world driving test cycles, J. Environ. Sci.-China, 76, 339348, https://doi.org/10.1016/j.jes.2018.05.026, 2019.

Yu, L., Wang, G., Zhang, R., Zhang, L., Song, Y., Wu, B., Li, X., An, K., and Chu, J.: Characterization and source apportionment of $\mathrm{PM}_{2.5}$ in an urban environment in Beijing, Aerosol Air Qual. Res., 13, 574-583, 2013.
Zhang, H., Cheng, S., Li, J., Yao, S., and Wang, X.: Investigating the aerosol mass and chemical components characteristics and feedback effects on the meteorological factors in the BeijingTianjin-Hebei region, China, Environ. Pollut., 244, 495-502, https://doi.org/10.1016/j.envpol.2018.10.087, 2019.

Zhang, M., Li, Z., Xu, M., Yue, J., Cai, Z., Yung, K. K. L., and Li, R.: Pollution characteristics, source apportionment and health risks assessment of fine particulate matter during a typical winter and summer time period in urban Taiyuan, China, Hum. Ecol. Risk Assess., 1-14, https://doi.org/10.1080/10807039.2019.1684184, 2019.

Zhang, Y., Yuan, Q., Huang, D., Kong, S., Zhang, J., Wang, X., Lu, C., Shi, Z., Zhang, X., Sun, Y., Wang, Z., Shao, L., Zhu, J., and Li, W.: Direct observations of fine primary particles from residential coal burning: Insights into their morphology, composition, and hygroscopicity, J. Geophys. Res.-Atmos., 123, 1296412979, https://doi.org/10.1029/2018JD028988, 2018.

Zhu, J., Penner, J. E., Lin, G., Zhou, C., Xu, L., and Zhuang, B.: Mechanism of SOA formation determines magnitude of radiative effects, P. Natl. Acad. Sci. USA, 114, 12685-12690, https://doi.org/10.1073/pnas.1712273114, 2017.

Zimmerman, N., Wang, J. M., Jeong, C., Ramos, M., Hilker, N., Healy, R. M., Sabaliauskas, K., Wallace, J. S., and Evans, G. J.: Field measurements of gasoline direct injection emission factors: Spatial and seasonal variability, Environ. Sci. Technol., 50, 2035-2043, https://doi.org/10.1021/acs.est.5b04444, 2016. 